\title{
PROBLEMS IN THE UTILIZATION OF THE BRAZILIAN CODE OF STRATI- GRAPHIC NOMENCLATURES AS RELATED TO MODERN RESEARCHES
}

\author{
SETEMBRINO PETRI ${ }^{1}$
}

\begin{abstract}
Some Brazilian stratigraphers, comparing Sequence Stratigraphy with previous established formations, stressed, in some examples, a supposed incompatibility of these stratigraphic systems. However, as the formation is the most objective unit of the code, a little flexibility in the definition of this unit, would avoid this incompatibility. Beside this consideration, this paper deals with examples of interpretative nature of some sequence propositions, taking as example, two different propositions of the same sequence, for the Devonian beds of the Brazilian Paraná Basin. The lithostratigraphical subdivision of these beds is discussed. Some published papers are discussed here in order to show that, as a rule, the depositional systems are dealed with by Brazilian stratigraphers, as a result of local (or regional) tectonics instead of eustatic worldwide sealevel fluctuations.
\end{abstract}

Keywords: stratigraphy, Brazilian code, modern researches.

\begin{abstract}
Resumo Alguns estratígrafos, aplicando Estratigrafia de Sequiências para a elucidação de ambientes de deposição de formações brasileiras, têm se confrontado com problemas de compatibilização de suas sequiências com as unidades litoestratigráficas formais.O caráter objetivo das unidades litoestratigráficas, principalmente formações, é aqui enfatizado, de modo que com alguma fiexibilização na definição de formação, a compatibilizaria com as sequiências. Para enfatizar a natureza interpretativa de algumas propostas de seqüências, dois exemplos são aqui citados envolvendo a mesma sucessão de camadas com propostas diferentes de seqüências. Variações litológicas dentro de unidade litoestratigráfica são discutidas. A maioria dos estratígrafos brasileiros considera os sistemas deposicionais, conseqüências de tectonismos locais ou regionais, não diretamente relacionados com flutuações eustáticas mundiais do nível do mar. A este respeito, transcrevem-se aqui exemplos de trabalhos publicados por alguns geólogos brasileiros.
\end{abstract}

Palavras-chaves: estratigrafia, código brasileiro, pesquisas modernas

INTRODUCTION Codes of stratigraphic nomenclature have been proposed since the mid $20^{\text {tl }}$ century, but their roots are grounded in earlier centuries. Mendes (1986) summarized their history. Mendes (1963) translated into Portuguese, the 1961 American Code of Stratigraphic Nomenclature, published by the American Commission on Stratigraphic Nomenclature. The Brazilian Code on Stratigraphic Nomenclature and a Guide with additional remarks were published in 1986 (Petri et al., 1986 a and $\underline{b}$ ).

Since the publications of the 1961 American Code and Hedberg's (1976), Guide of Stratigraphic Classification, many countries published their own codes. Successive versions publications of international codes, discussed and modified concepts in view of the needs to correct imperfections raised by practical uses of the code.

The 1961 American code, as well Hedberg's guide, were fundamentally based on three categories of units, litho, bio and chronostratigraphical. Further codes tended to increase the number of categories, resulted in unnecessary complexity of classification nomenclatures. So there were then propositions for nomenclature simplifications. These propositions do not mean suppressions of new techniques of investigations, but indeed, encouragement of their usages, but not as code categories.

Sequence Stratigraphy, for example, is a valuable approach for the purpose of narrowing the times involved in correlations of beds but trial to put it as taxonomic category resulted in a lot of controversies.

SEQUENCE STRATIGRAPHY AND THE STRATIGRAPHIC CODE Since the eighties of the $20^{\text {th }}$ century, the problem of the inclusion of Sequence Stratigraphy within the body of the stratigraphic units, is subject to debates. There are disagreements among the ISSC staff whether Sequence Stratigraphy is indivisible or split into two categories, one descriptive, called stratal, and other interpretative. These interpretative sequences may be reformulated as new evidence is gathered or as personal interpretations change (Salvador, 2003).

Brazilian examples of different interpretations of a Sequence Stratigraphy, involving the same succession of lithologies, are referred below.

The Brazilian Paraná Basin Devonian beds belong to two lithostratigraphic units: Furnas Formation mostly developed in marine coastal environment and Ponta Grossa Formation, laid down in more offshore marine environment.

Assine (1996; 2001), Bergamaschi (1999) and Bergamaschi \& Pereira (2001) recognized several sequences in these formations. Their interpretations were published in one volume edited by Melo \& Terra (2001).

In a locality called Pisa, close to Jaguariaiva city, State of Paraná, outcrop beds of Furnas Formation, rich in plant fossils. These plants lived in ancient lagoon. Assine $(1996 ; 2001)$ interpreted the Pisa beds as laid down in a marine coastal environment to where the plants were transported by storms. Hummocky cross-stratifications and lags of aligned dish-shape pebbles with no excavation structures below, would attest the reworked nature of the fossils. A transitional nature of Furnas to Ponta Grossa beds around Jaguariaiva, led Assine (1996; 2001) to characterize one sequence involving uppermost Furnas and lowermost Ponta Grossa.

Bergamaschi (1999) and Bergamaschi \& Pereira (2001), on the other hand, interpreted Pisa beds as indicative of lagoon, with plants living "in situ". They traced an unconformity between Furnas and Ponta Grossa and so considering them as representatives of two sequences. The gamma-ray logs as seen in the wells of Fig. 2, along the Furnas-Ponta Grossa contacts, allowed the interpretation of both sudden and transitional contacts. This situation would be possible only in a model of a sudden sea transgression in some places where the coastal beds 
were reworked. In other places, the conditions of topography or (and) currents favored a smooth advance of the sea so the coastal beds were not reworked. Bergamaschi (1999) and Bergamaschi \& Pereira (2001), on the ground of those sudden contacts in some places, proposed two different sequences, one for uppermost Furnas and another one for lowermost Ponta Grossa. However the gama-ray logs as well as some outcrops illustrate transitional beds, known since Petri (1948), so uppermost Furnas and lowermost Ponta Grossa make up only one stratigraphic sequence, as interpreted by Assine (1996; 2001).

LITHOLOGIC VARIANTIONS OF FORMATIONS The Ponta Grossa Formation is subdivided in three members: The lower Jaguariaiva, Tibagi and São Domingos, at the top (Lange \& Petri, 1967).

Grahn et al. (2000) restricted the Ponta Grossa Formation to the beds below Tibagi, so Jaguariaiva would be synonym of Ponta Grossa. Tibagi and São Domingos became then two independent formations. Even though these authors did not mention the criteria for this different nomenclature, it is believed here that they based on two papers: Oliveira (1916) who placed Tibagi on the top of Ponta Grossa, and Maack (1947) who proposed the new unit São Domingos.

Jaguariaiva and Tibagi have well defined type sections (Lange $\&$ Petri, 1967). They were continuously placed in the Ponta Grossa Formation since Clarke (1913) as "Ponta Grossa Series".

The Tibagi Member is representative of a regressive episode placed between two transgressive episodes, Jaguariaiva and São Domingos.

Some of the lithologic features of the Tibagi Member are seen in figures 2,3 and 4 .

The alternations of the lithologies (fine sandstones and silty shales are developed with varied thicknesses in the Tibagi Member. In the Tibagi locality (type of the member), $20 \mathrm{~m}$. of fine to silty sandstones are developed. In the Lambedor, thin beds of

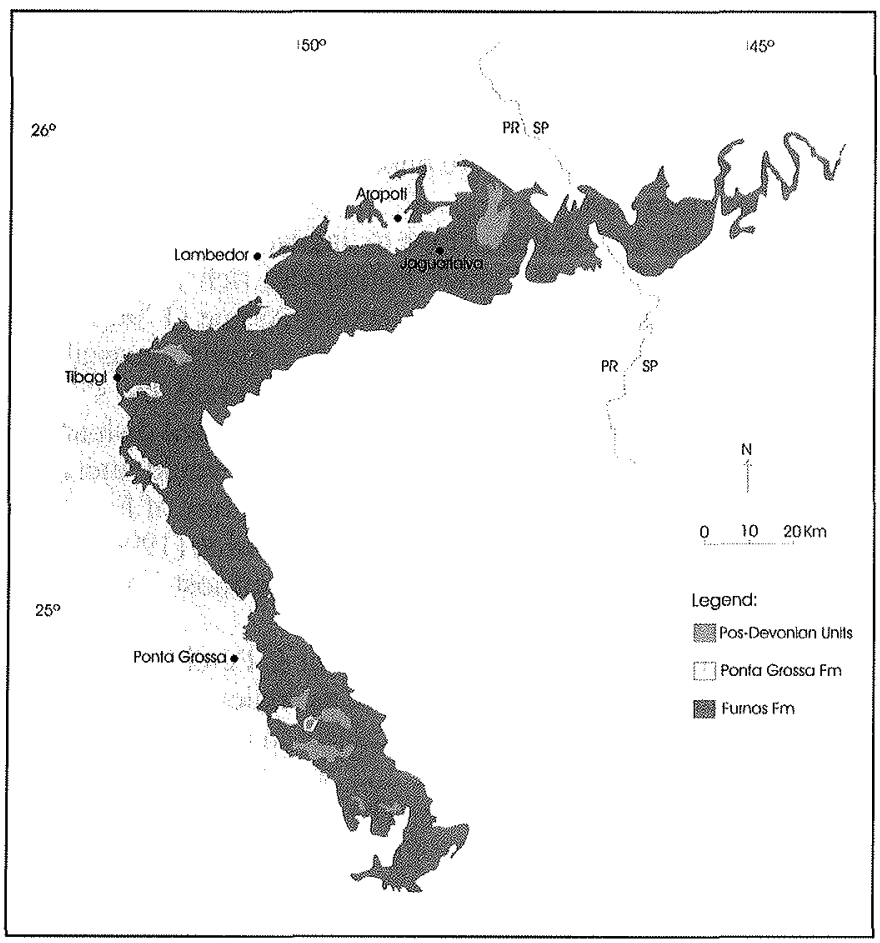

Picture 1 - Southwestern area of the Parana Basin with the mentioned localities in the text (modified from Assine, 1996 -Pic.7) fine sandstone and beds of silty shale occur, with recurrence of two faunas, according to the lithologies (Petri, 1948). In the Ponta Grossa city, the literature mentions two kinds of outcrops: one exposition, known since 1967 (Lange \& Petri, 1967), reproduced here as fig. 3 , is characterized by association of sandstones with hummocky cross-stratification with a lag of disk-shape pebbles laying on a flat surface; such structures remind those of Furnas. Dark gray shale, rich in plant remains and fragments of plants also are scatted in the sandstone. This outcrop reminds the top of the Furnas Formation by the associations of the structures. Also in the Ponta Grossa city, there are another occurrence of the Tibagi Member revealed in an excavation of a quarry for building rocks (Moro Quarry). This excavation revealed $20 \mathrm{~m}$ of fine to very fine bioturbated sandstone, covered by a coarse sandstone with small pebbles and with wave ripples. This outcrop was destroyed during quarrying.

At Alto Garças Sub-Basin, northern Paraná Basin (States of Mato Grosso do Sul, Mato Grosso and Goiás), there are outcrops of coarse and fine sandstones of this member.

These several lithologic characteristics of Tibagi Member i1lustrate how a lithostratigraphic unit may develop local details of lithology.

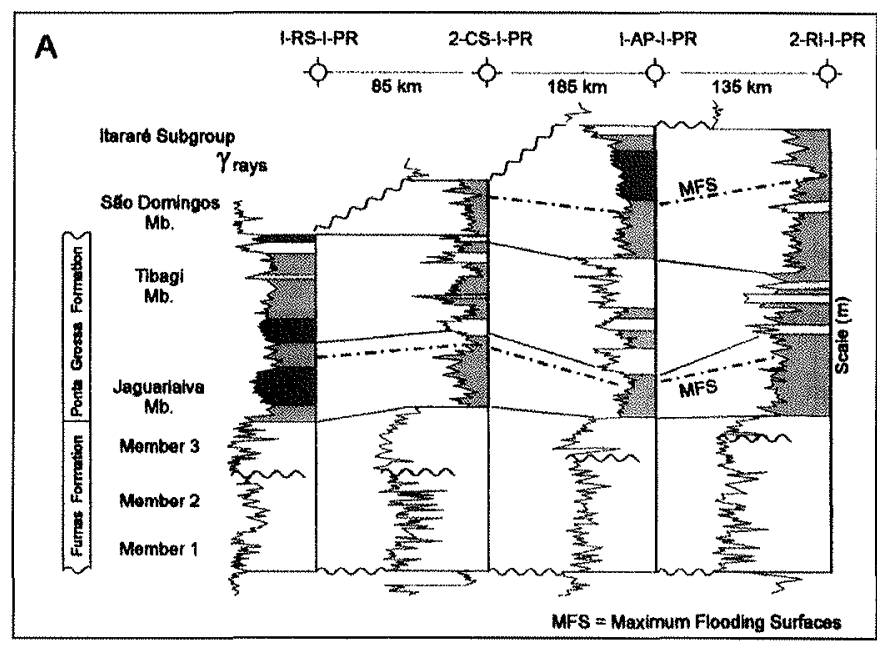

Picture 2a - Stratigraphic cross-section based on deep wells cutting Devonian beds - State of Paraná, Brazil. The lithostratigraphic units were recognized through gama-ray logs. Three lithostratigraphic units of Furnas Formation (not named) and three members of Ponta Grossa Formation (named) (modified from Assine et al., 1998, Pic 2)

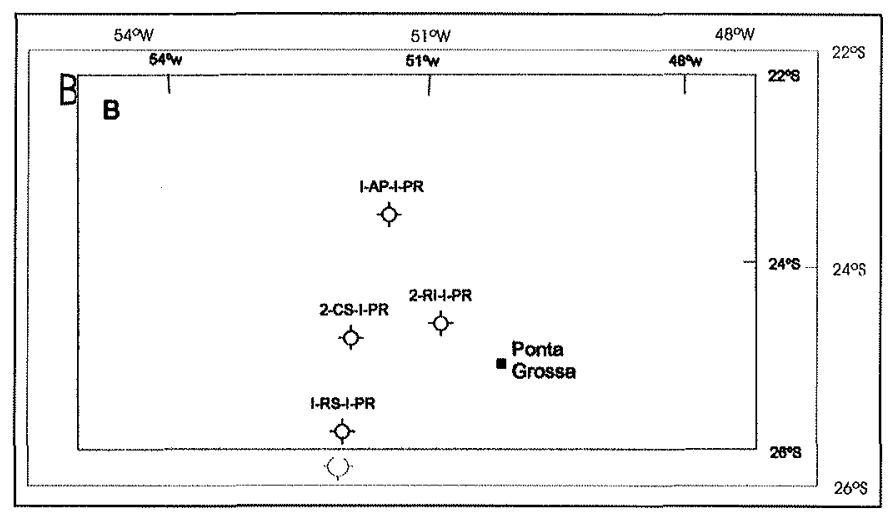

Picture $2 b$ - Geographic position of the four deep wells seen in Pic. $2 A$ 


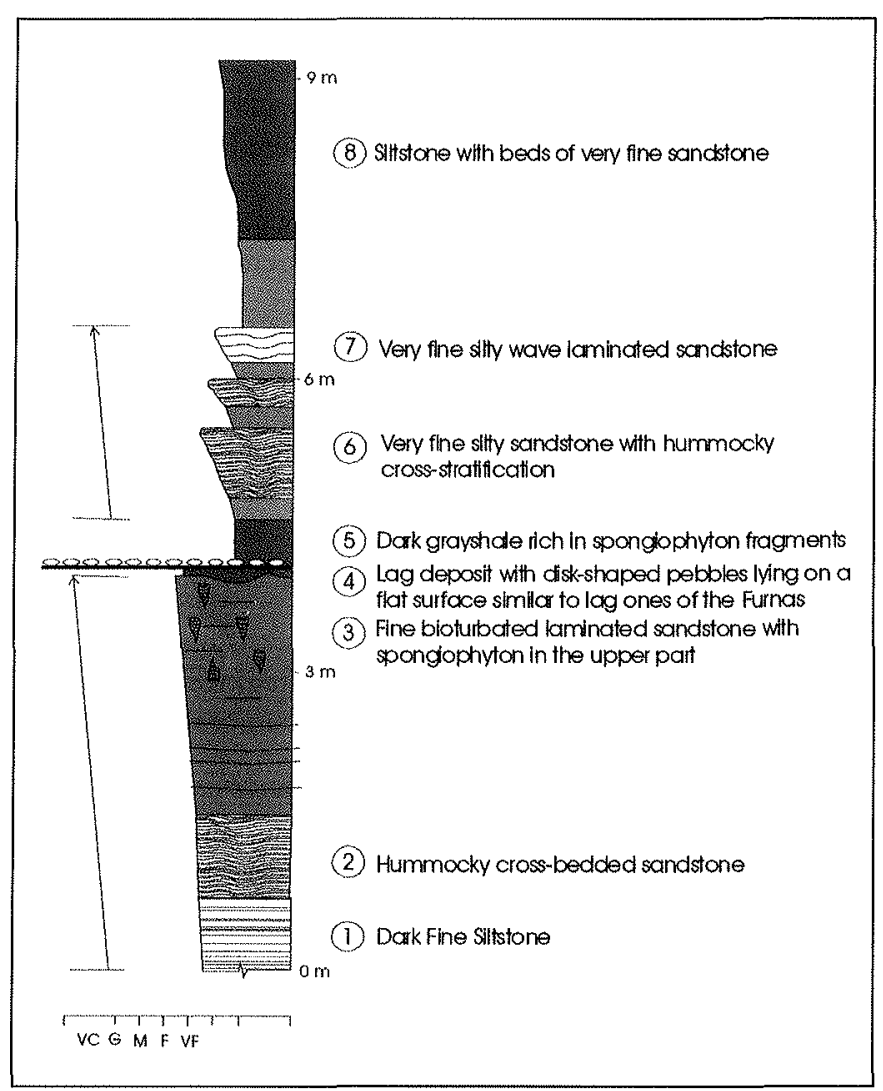

Picture 3 - Tibagi Member of the Ponta Grossa Formation, as developed in the Ponta Grossa City district Santa Luzia (old Central Paraná Basin railroad, Km 14,3). After Lange \& Petri (1967), modified by Assine (1996)

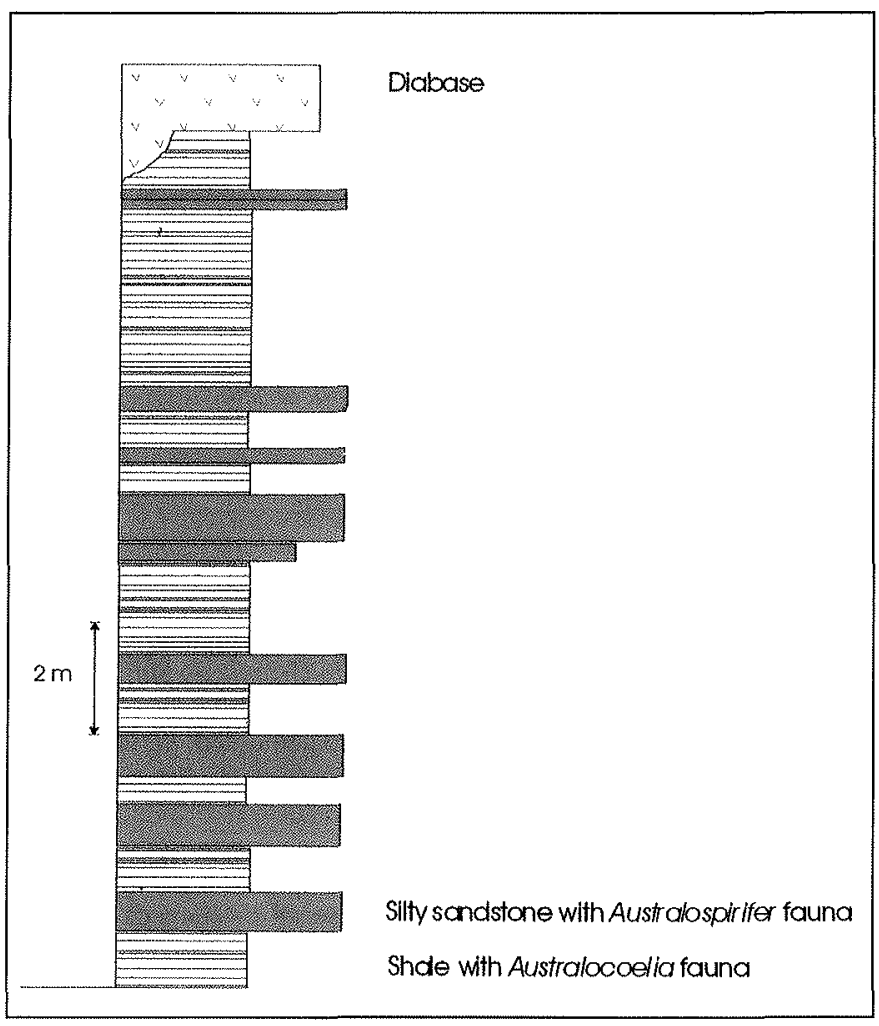

Picture 4 - Lambedor, State of Paraná, Brazil. Tibagi Member rhythmite (fine to silty sandstone and silty shale). Recurrence of two faunas, according to these two lithologies
DISCUSSION Most papers issued after the advent of Sequence Stratigraphy discussed both sequence and lithostratig raphy but place lithostratigraphic units as a prime importance. Sequence units from neighboring may differ in their sequence units. Viviers \& Azevedo (1988) point out that from Late Turonian to Maastrichtian, the Brazilian Santos marginal basin were subject to strong sediment influx, sediment coming from the adjacent continental "Serra do Mar" range, resulting in a prograding coast, whereas the neighboring Campos Basin, was under subsidence resulting in a retrogradation coast.

The Brazilian State of São Paulo north coast is now an submergent one whereas the south coast is a coast on emergence.

The Petrobras (Brazilian Petroleum Company) published in 1994, stratigraphical charts of most of the Brazilian sedimentary basins. Some examples of stratigraphical units picked up from these charts are reported here in order to stress the way most Brazilian stratigraphers deal with both litho and sequence stratigraphy:

Amazon Basin: Three Paleozoic stratigraphic sequences of second order are related to orogenic episodes. One CretaceousCenozoic sequence is related to Andean orogeny. Foz do Amazonas Basin: Triassic and Aptian/Albian rift sequences. A series of Cenomanian to Middle Miocene sequences related to several episodes of faultblocks uplifts and consequent erosions leading to the developments of fanglomerates prograding over marine beds. The formations were named according to their environmental sets, so the sequences were directly associated with these formations.

Ordovician beds, when present in the Brazilian sedimentary basins, always are small remnants of once larger units deeply eroded. These beds are frequently referred as independent sequences or part of a sequence together with Silurian beds. As remnants they probably should not be considered as complete sequences, eventually as sequence tracts.

Milani \& Ramos (1998) pointed out that the Paraná Ba$\sin$ Paleozoic sequences are related to the convergent western Gondwana plate against the Panthalassa margin and so they are not related to the North America Paleozoic sequences.

These examples stress the utmost importance of tectonism for the origin of sequences more than the eustatic origin for them and the lithostratigraphic units taken as references for the description of the sedimentary fillings of the basins.

The prime stratigraphical codes dealt mainly with layered sediments, effusive rocks or mildly metamorphic ones. Massive intrusive bodies, strong metamorphic rocks or complex bodies of these types of rocks are still at issue.

Certainly stratigraphy means more than nomenclature (Menegat \& Fernandes, 2003 a e b). Its holistic approach is important to understand processes of sedimentation, environments and tectonisms both at the sources and at the site of deposition. Holz et al. (2000), for example, scrutinized the agents that influenced the generation of Permian coals in the Brazilian states of Rio Grande do Sul and Santa Catarina, and concluded that the coals from Rio Grande do Sul came from lagoonal and related environments whereas the ones from Santa Catarina came from nearshore environments. Stratigraphic nomenclature, however, is the framework for other stratigraphic studies just as musical notes are the framework for melodies and harmonies.

The lithostratigraphic units are the result of extensive studies based on cores and a large number of outcrops leading to the recognition of their independence of the geological time. Misunderstanding this approach led to a following statement often repeated in papers on Sequence Stratigraphy: "Old stratigraphers considered the succession of beds as a layer-cake stratigraphy". Recognition that a lithology could cross chronological boundaries is found in papers as old as 1926 (Wright, W.B. in Mendes, 
1986). Writings in Brazilian literature also deny this "layer-cake stratigraphy". Petri (1948) considered Furnas and Ponta Grossa formations Devonian of the Brazilian Paraná Basin, as belonging to the same cycle of sedimentation, the first one more proximal and the second one laid down in a more distant marine environment and so, its contact were considered diachronous.

Holz \& Küchle (2003) considered the Rio Bonito Formation (Permian of Paraná Basin) as "heterodox", because this lithostratigraphic unit would not fit that stratigraphic sequences recognized by them. As lithostratigraphic units are independent of chronology and as the contact between two lithostratigraphic units may or not coincide with time lines and may be abrupt or transitional when then its limits will be arbitrary, the Holz \& Küchle sequences could be accommodated within the Rio Bonito Formation, with a little flexibility of definition of the formation. This lithostratigraphic unit may involve local unconformities or small gaps of sedimentation, keeping in mind that regional unconformities or drastic changes in framework of sedimentation were not involved. The stratigraphic sequences described by Assine (2001) and Bergamaschi \& Pereira (2001) mentioned above, cut the Ponta Grossa Formation.

Important procedure for naming a new unit is to carry out research as thorough as possible, to avoid the proposition of unnecessary formal names. Nowadays more researchers try to prevent the burden of stratigraphic names when describing lithostratigraphical significant bodies. Assine (1996), for example, discriminates three stratigraphically ordered units within the Furnas Formation but does not name them. On the other hand, names for the triple subdivision of the Ponta Grossa Formation, already present in the literature, were considered by him.

\section{CONCLUSIONS}

1. Lithostratigraphic units (especially formation) are the most objective ones and should not be dismissed.

2. The lithostratigraphic units, sticking to their definitions (especially the formation) may be harmonized with some stratigraphic sequences.

3. Sequences stratigraphies are local or regional. The regional ones are more suitable to be incorporated in the stratigraphic codes.

4. Allostratigraphy (and synthem) should be discarded as synonyms of formation (eventually group).

\section{References}

American Commission on Straligraphic Nomenclature. 1961. Code of straligiaphic nomenclature - Am. Ass. Petr. Geol., Bull., 45(5): 645 665. (Translated to Portuguese by Mendes, 1963)

Assine, M.L. 1996. Aspectos da estratigrafia das sequuências pré-carboniferas da Bacia do Paraná - Inst Geoc.Univ. S.Paulo - Doctor. Thesis: $207 \mathrm{p}$.

Assine, M.L. 2001. O ciclo devoniano na Bacia do Paraná e correlação com outras bacias gondwânicas - In Melo, L.H.G. \& Terra, C.J.S. (eds.) Correlação de sequiencias paleazóicas sulamericanas - Petrobras - Seç. Expl. Petr., 20: 55-62.

Assine, M.L.; Perinotto, J.A.J.; Fulfaro, V.J. \& Petri, S. 1998. Progradação deltaica Tibagi no Devoniano Médio da Bacia do Paraná - Rev. Bras. Geoc,. 28(2): 125-134.

Bergamaschi, S. 1999. Análise estratigráfica do Siluro-Devoniano (formações Furnas e Ponta Grossa) da Sub-bacia de Apucarana, Bacia do Paraná, Brasil - Inst. Geoc. Univ. S. Paulo - Doctor Thesis: $167 \mathrm{p}$.

Bergamaschi, S. \& Pereira, E. 2001. Caracterização de seqüências deposicionais de terceira ordem para o Siluro-Devoniano da Sub-bacia de Apucanina, Bacia do Paraná, Brasil - In Melo, J.H.G. \& Terra, C.J.S. (eds.). Correlação de seqüências paleozóicas sulamericanas - Petrobrás - Seç. Expl.Petr., 20: 63-72.

Clarke, J.M. 1913. Fósseis Devonianos do Paraná (Portuguese and English) - Serv. Geol. Min., Brasil, Monogr. 1: 353p.

Grahn, Y; Pereira, E.; \& Bergamaschi, S. 2000. Silurian and lower Devonian chitinozoan biostratigraphy of Paraná Basin in Brazil and Paraguay - Palynology, 24: 63-72.

Hedberg H.D. (ed.) - 1976 - A guide to stratigraphic classification: teminology and procedure (ISSC) - John Wiley and Sons: 200p.

Holz , M. \& Küchle, J.A. 2003. A Formação Rio Bonito no sul da Bacia do Paraná: uma discussão "heterodoxa" de litoestratigrafia versus estratigrafia de sequências. In: Hartmann, L. A. (ed.) - Primeiro encontro sobre a Estratigrafia do Rio Grande do Sul - Escudos e bacias: $151-157$

Holz, M.; Vieira, P.E. \& Kilkreuth, W. 2000. The early Permian coal bearing succession of the Paraná Basin in southernmost Brazil: depositional model and sequence stratigraphy - Rev. Bras. Geoc., 30(3): 424-426.

Lange F.W. \& Petri, S. 1967. The Devonian of the Paraná Basin - Bol. Paran. Geoc., 21/22: 5-55.

Maack, R. 1947. Breve notícia sobre a geologia dos estados Paraná e Santa Catarina - Inst. Biol. Pesq. Tecn. - Arq. Biol., 2: 63-154.

Melo, J.H.G. \& Terra, C.J.S. (eds.). 2001. Correlação de seqüências paleozóicas sulamericanas. Petrobrás - Séc. Expl. Petr, 20: 222 p.

Mendes, J.C. 1963. Código de Nomenclatura Estratigráfica - Inst. Geol. Univ. Fed. Pernambuco, sér didática: $58 \mathrm{p}$.

Mendes, J.C. 1986. Evolução da classificação estratigráfica. Rev. Bras Geoc., 16(4): 371-372.

Menegat, R. \& Fernandes L.A.D. 2003 a . A nova mente da estratigrafia e os padrões de explicação geológica - Parte 1 - Da classificação estratigráfica à estratigrafia de modelos. In: Hartmann, L. A. (ed.) - Primeiro encontro estratigráfico do Rio Grande do Sul: 158-160. 2003 b. A nova mente da estratigrafia e os padrões de explicação geológica - Parte 2 - Modelos do registro geológico, In: Hartmann, L. A. (ed.) - Primeiro encontro estratigráfico do Rio Grande do Sul: 161-163.

Milani, E.J. \& Ramos, V.A. 1998. Orogenias paleozóicas no domínio sul-ocidental do Gondwana e os ciclos de subsistência da Bacia do Paraná. Rev. Bras. Geoc., 28(4): 473-484.

Oliveira, E.P. 1916. Geologia do E do Paraná, Brasil - Min. Agricult. Ind. e Com., Bol. 5(1): 67-143.

Petri, S. 1948. Contribuição ao estudo do Devoniano paranaense Dep. Nac. Prod. Min., Bol. 129: 125p. Petri, S.; Coimbra, A. M.; 
Amaral, O.; Ojeda, H.O.; Fulfaro, V \& Ponçano, W.L. 1986 a. Código brasileiro de nomenclatura estratigráfica - Rev. Bras. Geoc. 16(4): 372-376. 1986 b. Guia de nomenclatura estratigráfica - Rev Bras. Geoc., 16(4): 376-415. Petrobrás - Comitê Editorial de Geociências 1994. Boletim de Geociências, 8(1): 249 pp.

Salvador, A. 2003. Review or the concepts of and recommended terminology for unconformity related units - Intern. Subcom. on Stratigr. Classification (ISSC), newsletter 1 (Circular 102) - Feb. 2003:
$17-19$.

Viviers, M.C. \& Azevedo, R.L.M. 1988. The southeastern area of the Brazilian continental margin: its evolution during the middle to late Cretaceous as indicated by paleoecological data. Rev. Bras. Geoc., 18(3): $291-298$.

Manuscrito A-A-1517

Revisão aceita em 14 de junho de 2006 
